\title{
ジオテキスタイルで補強されたセメント改良 補強盛土からなる橋台の耐震設計
}

幸原 淳 1 青木一二三 2 米澤豊司 3 ・渡邊 修4 ・舘山 勝 5 龍岡文夫 6

\begin{abstract}
兵庫県南部地震をはじめとするレベル 2 地震動に対し，橋台と橋台背面盛土を含めた橋台部全体系の耐震性 能の向上が重要な課題となっている. 現在、日本鉄道建設公団・鉄道総合技術研究所・東京大学では, 共同研 究として耐震性能を有する合理的な新しい形式の橋台の研究開発を実施している. 本論文は, まずジオテキス タイルで補強されたセメント改良補強盛土からなる橋台（以下「セメント改良補強土橋台」という．）の耐震 設計法の考え方を示し，さらに実際に適用が予定されている橋台に対して，セメント改良補強土橋台と従来形 式の逆 $\mathrm{T}$ 式橋台の比較設計を行った結果を述へる. 比較設計の結果, セメント改良補強土橋台は耐震性のうえ でも，また経済性のうえでも従来形式の橋台に比へて優れていることが明らかとなった。
\end{abstract}

キーワード : セメント改良補強土橋台, 静的非線形解析, 限界状態設計

\section{1. 計画概要}

図ー1に示すよう に，地震時におけ る橋台背面盛士は 沈下が生じやすく, 鉄道において軌道 の沈下は列車の走 行安定性に対し重 大な影響を与える。 日本鉄道建設公 団・鉄道総合技術 研究所・東京大学 では, L 2 地震動

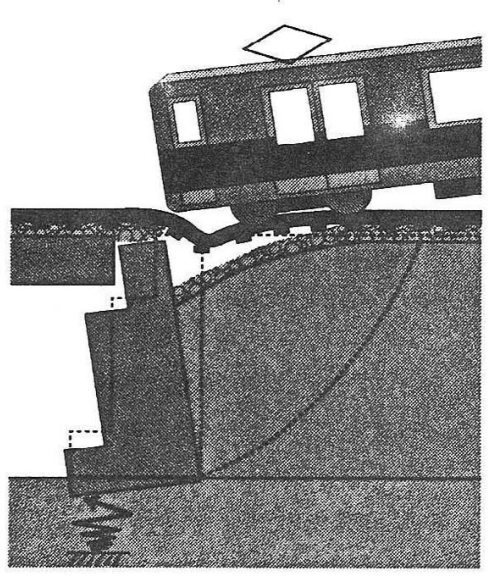

图-1 橋台背面盛土の沈下
に対しても十分な耐震性を有し, かつ合理的な橋台構造 を開発するため, 各種橋台タイプに対する振動実験を実 施し，その対策効果を明らかにしてきだん可.

さらに，それらの結果を踏まえ て抜本的に耐震性を向上させた新 しい橋台構造であるジオテキスタ イルを用いた「セメント改良補強 土橋台」と「PLPS 補強土橋台 ${ }^{1)} 」$ を提案した.

本論は,このうち九州新幹線 (博多一西鹿児島間) で実施設計 された「セメント改良補強土橋
台」について,

(1)設計の考え方ならびに検討結果

(2)従来の逆T式橋台との比較設計結果

(3) 実施試験計画

の三項目について報告する.

\section{2.セメント改良補強土橋台の構造概要}

セメント改良補強土橋台は，地震時に橋台背面で発 生する盛土の摇り込み沈下と，橋台変形による段差対策 に有効であることが確認されている゙（图-2参照)。

粒度調整砕石をセメント改良して固結させたアプロー チブロックは，摇り込み沈下対策として新幹線に使用さ れている．段差対策としては，橋台をジオテキスタイル で連結する方法が考えられる. セメント改良補強土橋台 は両長所を合わせた橋台形式として開発された。

1復建調查設計株式会社 鉄道事業部（广101-0032 東京都千代田区岩本町3-8-15） ${ }^{2}$ 正会員, 日本鉄道建設公団 設計技術室, 主任 技師（テ1000014 東京都千代田区永田町2-14-2 山王グランドビル6F） ${ }^{3}$ 正会員, 同2, 補佐 4同2, 九州新幹線建設局 計画課 （テ812-8622 福岡市博多区祇園町2-1 博多祇園21ビル） 5 正会員，（財）鉄道総合技術研究所構造物技術研究部 基礎土構造，研 究室長（广185-8540 東京都国分寺市光町2-8-38） ${ }^{6}$ 止会員, 東京大学大学院工学研究科 社会基盤工学専攻, 教授（广1138656 東京 都文京区本郷7-3-1) 


\section{3. セメント改良補強土橋台の設計法 \\ (1) 設神の考え方}

a) 長期使用，終局限界状態の設計

セメント改良補強土橋台の地震時を除く限界状態 設計は，基整標準》に基づき，表-1に示すように従 来橋台と同様の安定検討ならびに部材検討を行うこ ととした. 橋台く体は，実際には背面をジオテキス タイルで慗がれた状態であるが，安定検扵は背面土 のう部の主働土圧のみを考虑し，桁設計荷重，自重 を算定して支持力度ならびに鉛直水平支持力の照査を 行う (图-3参照).

ジオテキスタイルで補強されたセメント改良体補強 部は重力式推壁と仮定し, 軌道重量と自重ならびに仮 想背面を想定した盛土重量と主働土压をそれぞれ算定 し安定検討を行う。

なお，施工時の検討はセメント改良体が固まらない 条件で補强土として設計を行い，補強材の配置を定め る.

\section{b) 耐震設計}

現在，鉄道における橋台は，耐震標蕉》により，限界 状態設計法をベースとした性能照查型設計により耐震設 計がなされている.そこで，セメント改良補强土橋台に ついても，同様の方法をベースとした耐震設計法の検討 を行うこととした. 图-4に本橋台の耐震設計モデルを示 し, セメント改良体の地震時に対する設計の考え方と橋 台く体の静的非線形解析（Push-Over解析）のモデル化に ついて示す.

本構造は，背面のセメント改良体と橋台く体がジオ テキスタイルによって接合された複合構造物である. 設 計にあたっては，セメント改良部と橋台く体部を分けて モデル化し，それぞれに対して設計することとした。

各部材に要求される耐震性能を表-2に示す。橋台全体 の安定検討は, L1地震動に対しては設計許容支持力以 内，L2地震動に対しては許容支持力を超えるため塑性 率*制限值以下とした.

ジオテキスタイルは, L1 地震動に対して設計破断强 度以内, L2地震動に対しては上部1及が最大引張力に達 することを許容することとした.

セメント改良体は，L2地震動に対してせん断応力が

表-2 各部材に要求される耐震性能

\begin{tabular}{|c|c|c|}
\hline 設計想定地震動 & L1 地震動 & L2 地震動 \\
\hline 地震時安定検討 & 許容支持力以内 & 塑性率制限值 $\left(\mu_{\mathrm{L}}=3\right)$ 以内 \\
\hline 橋台躯体の損傷 & $\begin{array}{l}\text { 弾性範囲内 } \\
\text { 損偒レベル I }\end{array}$ & $\begin{array}{l}\text { 最大耐力以内 } \\
\text { 損傷レベル II }\end{array}$ \\
\hline $\begin{array}{l}\text { ジオテキスタイ } \\
\text { ルの損傷 }\end{array}$ & $\begin{array}{l}\text { 設計破断強度以 } \\
\text { 内 }\end{array}$ & $\begin{array}{l}\text { 上部 } 1 / 3 \text { が最大引張力に } \\
\text { 達することを許容 }\end{array}$ \\
\hline $\begin{array}{l}\text { セメント改良体 } \\
\text { の損鹪 }\end{array}$ & 許容応力度以内 & $\begin{array}{l}\text { せん断クラックを許容 } \\
\text { 残留変位量が許容以下 }\end{array}$ \\
\hline
\end{tabular}

*: 地震時における構造物の応答変位の降伏変位に対寸る比.
表-1 地震時を除く限界状態設計（安定検討）

\begin{tabular}{|c|c|c|}
\hline 項目 & 〈体 & セメント改良体補強部 \\
\hline 設計荷重 & $\begin{array}{l}\text { 杵荷重,〈体自重, } \\
\text { 土のう部主働土压 }\end{array}$ & $\begin{array}{c}\text { 軌道, 列車荷重, 自重 } \\
\text { 背面主働土圧 }\end{array}$ \\
\hline $\begin{array}{l}\text { 長期使用限界 } \\
\text { 使用限界状態 }\end{array}$ & 設計地盤反力度 $q_{d}$ & 設計地盤反力度 $q_{d}$ \\
\hline 終局限界状態 & 設計地盤支持力 $R_{w d}$ & 設計地盤支持力 $R_{\mathrm{wd}}$ \\
\hline 水平力(各状態) & 設計水平支持力 $R_{h d}$ & 設計水平支持力 $R_{h d}$ \\
\hline
\end{tabular}

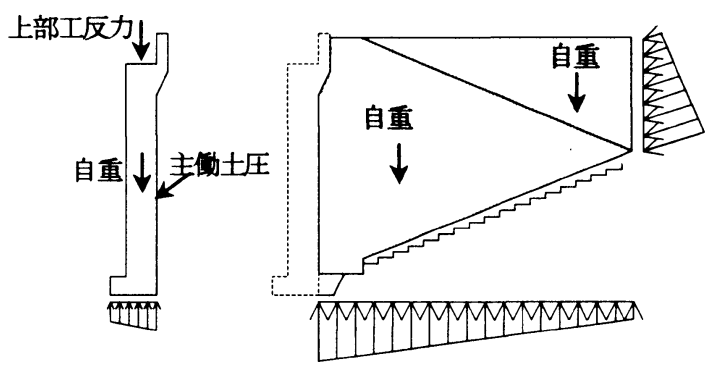

図-3 安定検討略図（地震時を除く）

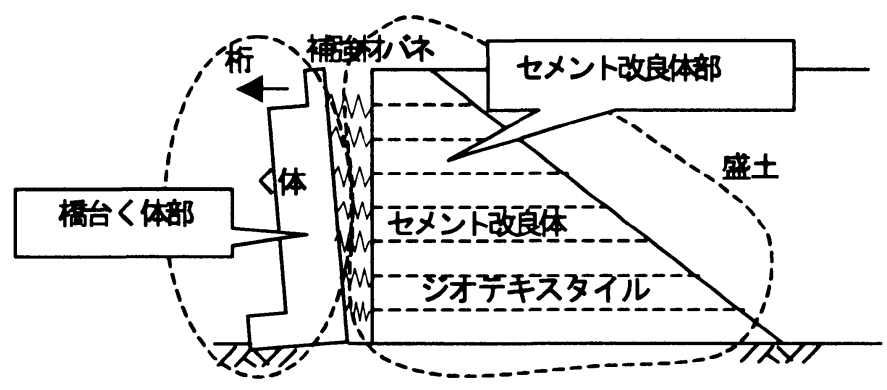

图-4 セメント改良補強土橋台の耐震設計モデル
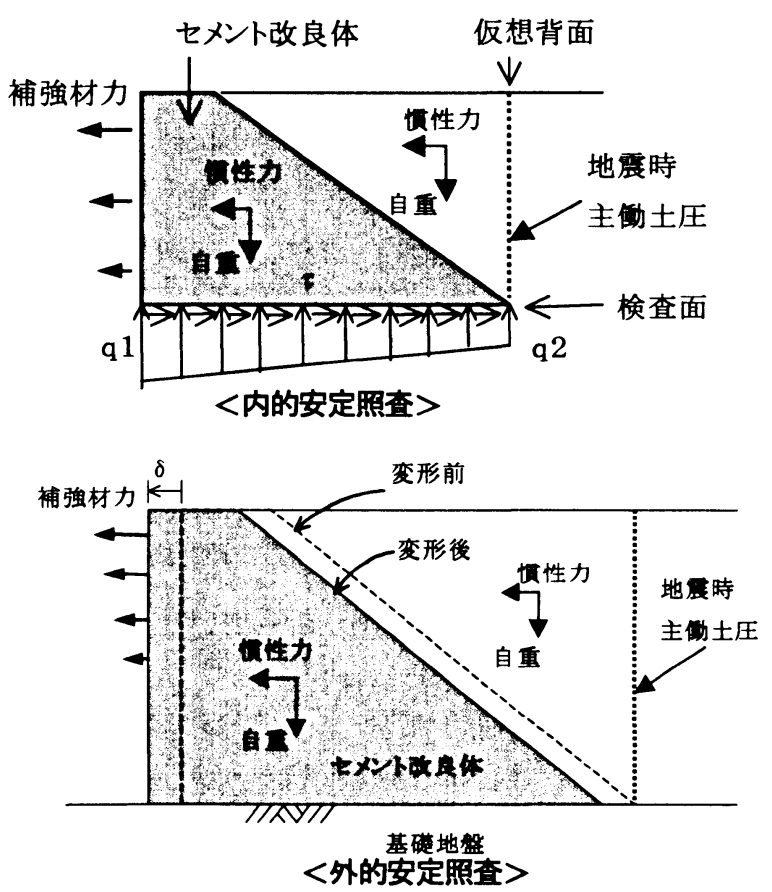

図-5 セメント改良体部の設計モデル 
許容応力度を超えてクラックを生じた場合, ニューマー ク法により滑動变形量を算出し, 残留变位量が許容変形 量以内であることを照査することとした. 外力としては, 橋台く体の静的非線形解析による補強材力, 改良体の自 重, 地震慣性力, 盛土からの地震時主働土圧（修正物 部・岡部の地震時主働土圧式》）とした.

橋台く体は図一に示す棒部材とし，基硠地盤は回転バ ネおよび水平バネ, 補強材は水平バネでモデル化する. また, く体の非線形性はM-中モデル，補強材バネおよび 基礎地盤バネはバイリニア, トリリニアモデルとした. このモデルに対する静的非線形解析で得られる荷重〜変 位関係からエネルギー一定則により応答值を算定し, 部 材の破壊モードや基礎の塑性率を耐震標準 に淮拠して 照查することとした。く体はL1地震動に対し損傷レべ ル I (全ての部材が降伏M,以下), L2地震動に対しては 損傷レベル II (部材が非線形領域に入ることは許容する が, く体の最大耐力 $\mathrm{M}_{\mathrm{m}}$ 以下）とした.

\section{4. 実施設計}

\section{（1）設計条件}

実施設計を行ったセメント改良補強土橋台の一般図を 図-7に示し，以下に設計条件を示す.

(1) 線路規格：九州新幹線（博多一新八代間）

(2) 列車荷重 : P-16 活荷重, 設計速度 : V = 260km/

(3) 上部工 : RC 単純 $\mathrm{T}$ 桁 $(\mathrm{L}=15 \mathrm{~m})$

(4) 支持地盤：風化凝灰岩 $(\mathrm{N}$ 值 $\geqq 50)$

(5) く体コンクリート設計基淮強度 : $\sigma_{\mathrm{d}}=24 \mathrm{~N} / \mathrm{mm}^{2}$

(6) 設計水平震度 : 0.54 (L2 地震動), 0.10 ( L1 地震動)

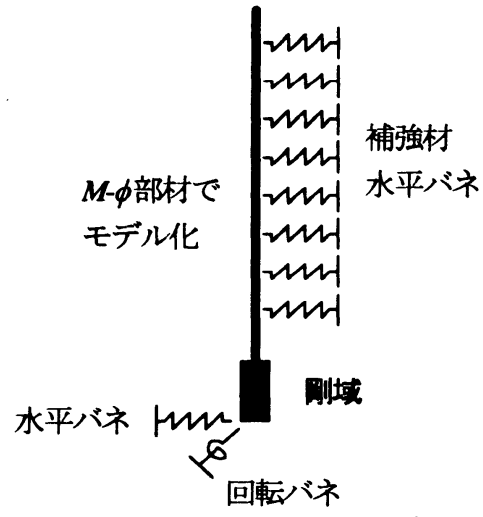

図-6 く体の設計モデル

(7) 補強材引張強度 : $30 \mathrm{kN} / \mathrm{m} （ \mathrm{~L}=1.5 \mathrm{~m}$ 用) $60 \mathrm{kN} / \mathrm{m}$ （ $>1.5 \mathrm{~m}$ 用）

(8)セメント改良体(粒調砕石)の設計基準強度 :

\section{（2）地䨘状況}

$\mathrm{q}_{\mathrm{u}}=2000 \mathrm{kN} / \mathrm{m}^{2}$

橋台予定地は，沖積低地に面した傾斜角 $20^{\circ}$ の緩勾配 斜面に位置する. 表層は磷混じり砂からなる崖錐堆積物 (dt)で，その下に風化結晶片岩(wSct)が4～6m近く分布す る. N值は深度方向に増加するが全体的に風化している ため，支持層はこれより下の結晶片岩(Sct)（N值 ミ50） とした.

\section{（3）ジオテキスタイルの数設}

ジオテキスタイルの敷設方法および強度は, 長物 （L>1.5m）を60kN/m，900mmピッチに敷設し，等長物 (L=1.5m) は30kN/m，300mmピッチで60kNの間を埋める 敷設形式とした.

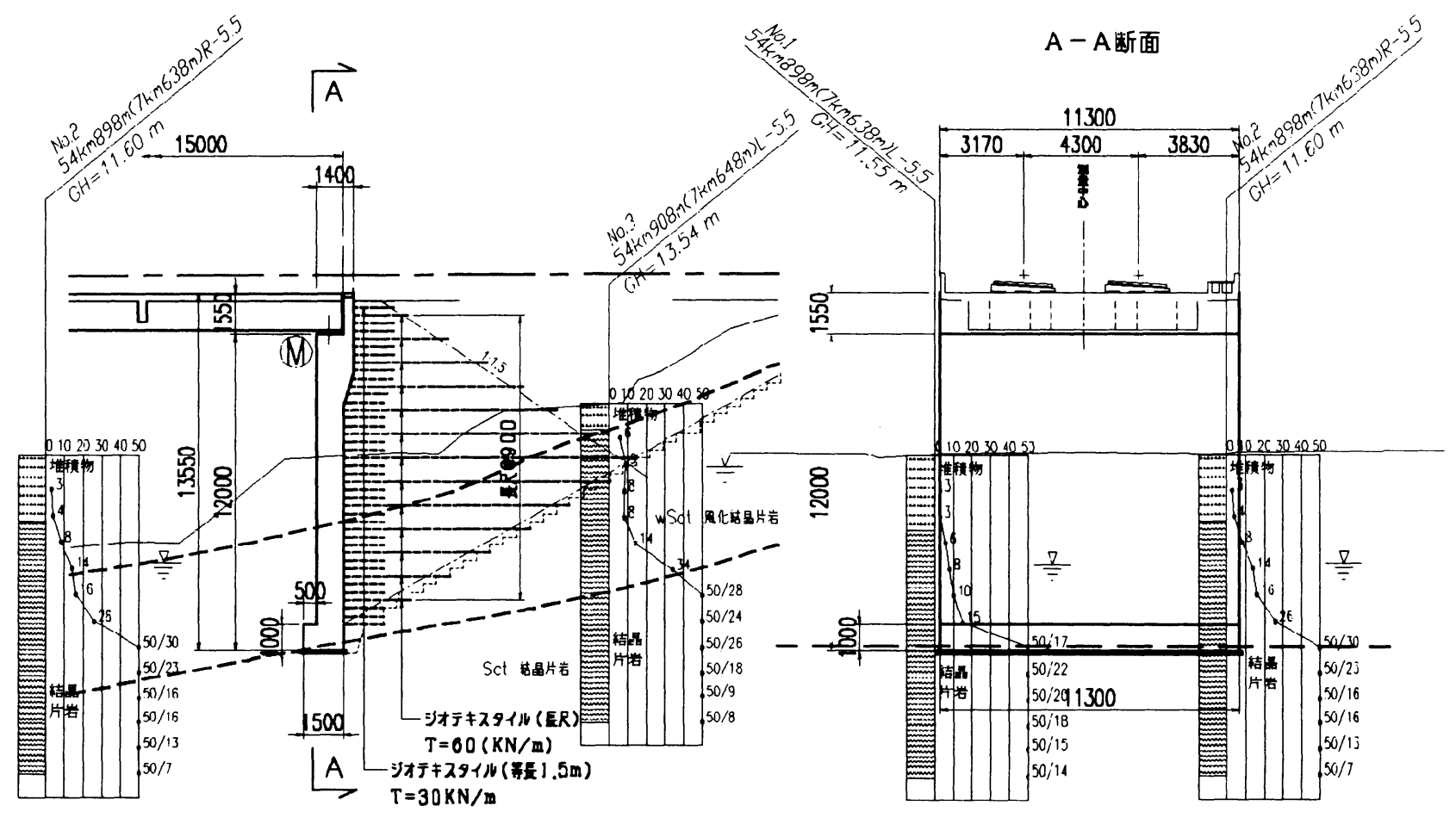

図-7 セメント改良補強土橋台計画図 (単位：mm) 
（4）検討結果

\section{a) 安定検討結果}

表-3に安定検討結果を示す。橋台く体の長期使用時 の鉛直支持力度は, 許容值に対して安全率 ${ }^{*}=0.74<1.0$ となった（表-3）。〈体は桁と列車荷重を直接支持す ることから, 新幹線RC構造物として十分な安全度を 確保することが望ましいため, 安全率に余裕を持たせ, フーチング基礎幅は $1.5 \mathrm{~m}$ とした。

セメント改良体つ鉛直支持力度は，支持地盤をN值 $\Rightarrow$ (風化凝灰岩) とした結果, 使用限界時の安全率は 0.96となった。 なお，終局限界状態ならびにL1地震動 に対する検討は全て安全となった。

セメント改良体のL2地震時の水平力は，〈体によ る設計水平力がジオテキスタイルを介して改良体に作 用する他，改良体の自重慣性力ならびに背面盛土の自 重慣性力と地震時主働土圧を考慮した. 照査の結果, 転倒モーメントによる設計鉛直力が許容支持力を超え るため塑性設計となり，塑性率は $\mu_{\mathrm{d}}=2.58<3$ （=制限 值) となった.

\section{b) ジオテキスタイルとセメント改良体の検封結果}

橋台く体の静的非線形解析による補強材引張り力は 胸壁背面で最大 $20.3 \mathrm{kN} / \mathrm{m}$ （表-4）を示し，下方に向け て徐々に低下した。これは桁水平力が支承位置（図-8 節点5）に作用するためと考えられ，セメント改良体 の設計せん断力も同様であった（表-5).

また, 補強材の引張りカとセメント改良体の内的応 力は，共に許容值に対して十分小さく安全であったた め, 残留变位の検討は行わなかった. なお，ジオテキ スタイルの30k $/ \mathrm{m}$ と $60 \mathrm{kN} / \mathrm{m}$ の組合せについては, 桁 および橋台の規模, 設計水平震度の大きさにより変化 させる必要がある.

\section{c）〈体の断面照査結果}

橋台く体は，図-8に示すモデルで静的非線形解析を 行った. 検討の結果, く体は曲げ降伏耐力以下であっ た.

$\mathrm{M}_{\mathrm{c}}=1432 \mathrm{kN} \cdot \mathrm{m}<\mathrm{M}_{\mathrm{y}}=10159 \mathrm{kN} \cdot \mathrm{m}$ (部材8損伤ベル I )

$\left(\mathrm{M}_{\mathrm{d}}\right.$ : 設計曲げモーメント, $\mathrm{M}_{\mathrm{y}}$ : 降伏曲げモーメント) 1000400

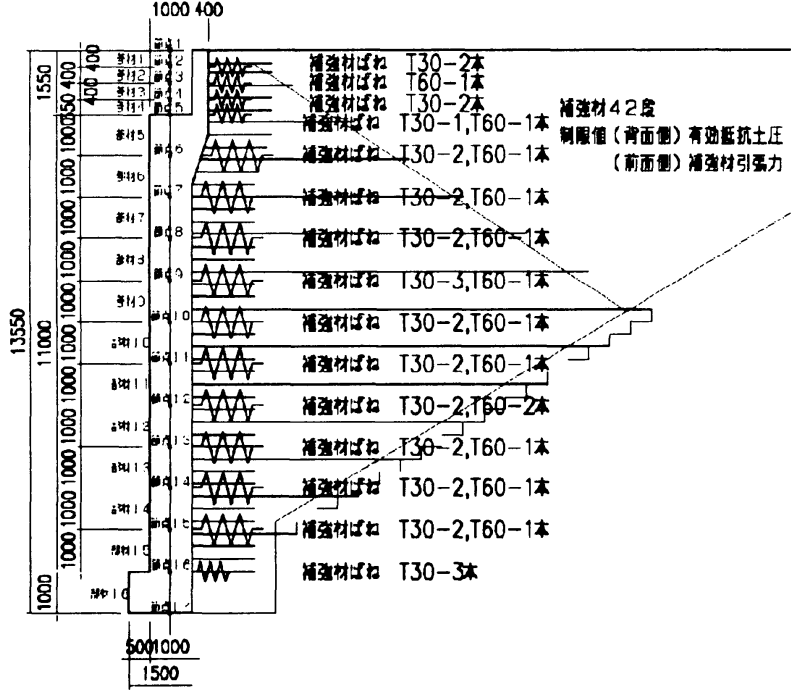

表-3 安定検討結果

\begin{tabular}{|c|c|c|c|c|}
\hline \multirow{4}{*}{ 鉛直支持力度 } & $\left(\gamma_{i}=1.0\right)$ & 単位 & 長期使用 & 使用限界 \\
\hline & $P_{d 1}$ & $\mathrm{kN} / \mathrm{m}^{2}$ & 283 & 276 \\
\hline & $q_{1}$ & $\mathrm{kN} / \mathrm{m}^{2}$ & 305 & 289 \\
\hline & ${ }^{*} \gamma_{\mathrm{i}} \cdot \mathrm{P}_{\mathrm{d}} / \mathrm{q}_{\mathrm{d}}$ & - & $0.93<1.0$ & $0.96<1.0$ \\
\hline \multirow{4}{*}{$\begin{array}{c}\text { 鉛直支持力度 } \\
\text { (〈体の安定) }\end{array}$} & - & - & 長期使用 & 使用限界 \\
\hline & $\mathbf{P}_{\mathrm{dl}}$ & $\mathrm{kN} / \mathrm{m}^{2}$ & 423 & 473 \\
\hline & $q_{d}$ & $\mathrm{kN} / \mathrm{m}^{2}$ & 568 & 731 \\
\hline & ${ }^{*} \gamma_{\mathrm{i}} \cdot \mathrm{P}_{\mathrm{dl}} / \mathrm{q}_{\mathrm{d}}$ & - & $0.74<1.0$ & $0.65<1.0$ \\
\hline \multirow{4}{*}{ 鉛直支持力 } & - & - & 終局限界 & L1地震時 \\
\hline & $\mathbf{V}_{\mathrm{d}}$ & $\mathbf{k N}$ & 28206 & 23418 \\
\hline & $R_{\text {dd }}$ & $\mathbf{k N}$ & 37768 & 27734 \\
\hline & ${ }^{*} \gamma_{\mathrm{i}} \cdot \mathrm{V}_{\mathrm{d}} / \mathrm{R}_{\mathrm{cd}}$ & - & $0.75<1.0$ & $0.84<1.0$ \\
\hline \multirow{4}{*}{ 水平支持力 } & - & - & 終局限界 & L1地震時 \\
\hline & $\mathrm{H}_{\mathrm{d}}$ & $\mathbf{k N}$ & 1183 & 4236 \\
\hline & $\mathbf{R}_{\mathrm{hd}}$ & $\mathbf{k N}$ & 10866 & 10746 \\
\hline & ${ }^{*} \gamma_{\mathrm{i}} \cdot \mathrm{H}_{\mathrm{d}} / \mathrm{R}_{\mathrm{hd}}$ & - & $0.11<1.0$ & $0.39<1.0$ \\
\hline \multirow{4}{*}{$\begin{array}{c}\text { 塑性率 } \\
\text { (セxント改良体) }\end{array}$} & - & - & \multicolumn{2}{|c|}{ L2地震時 } \\
\hline & $\mu_{\mathrm{d}}$ & - & \multicolumn{2}{|c|}{2.58} \\
\hline & $\mu_{\mathrm{L}}(=3.0)$ & - & \multicolumn{2}{|c|}{3.0} \\
\hline & ${ }^{*} \gamma_{\mathrm{i}} \cdot \mu_{\mathrm{d}} / \mu_{\mathrm{L}}$ & - & \multicolumn{2}{|c|}{$0.86<1.0$} \\
\hline
\end{tabular}

* : 設計力/許容力の值を示し, 安全率が 1.0 以下の場合に許容 内（安全側）となる（表-4，表一 5 も同様）.

表-4 ジオテキスタイルの検討結果

\begin{tabular}{|c|c|c|c|}
\hline (構造物係数 $\gamma_{\mathrm{i}}=1.0$ ) & 単位 & L1 地震動 & L2地震動 \\
\hline \multicolumn{4}{|l|}{ 補強材 : $\mathrm{T}=30 \mathrm{kN} / \mathrm{m}$} \\
\hline 照查位置 & & 2節点 & 4節点 \\
\hline 設計引張り力 T & $\mathbf{k N} / \mathbf{m}$ & 1.8 & 8.1 \\
\hline 補強材引張り強度 Ta & $\mathrm{kN} / \mathrm{m}$ & 30.0 & 30.0 \\
\hline$* \gamma_{\mathrm{i}} \cdot \mathrm{T} / \mathrm{Ta}<1.0$ & & $0.06<1.0$ & $0.27<1.0$ \\
\hline \multicolumn{4}{|l|}{ 補強材： $\mathrm{T}=60 \mathrm{kN} / \mathrm{m}$} \\
\hline 照查位置（ $\gamma_{1}=1.0 ）$ & & 2節点 & 3節点 \\
\hline 設計引張り力 T & $\mathrm{kN} / \mathrm{m}$ & 4.4 & 20.3 \\
\hline 補強材引張り強度 Ta & $\mathrm{kN} / \mathrm{m}$ & 60.0 & 60.0 \\
\hline${ }^{*} \gamma_{\mathrm{i}} \cdot \mathrm{T} / \mathrm{Ta}<1.0$ & & $0.07<1.0$ & $0.34<1.0$ \\
\hline
\end{tabular}

表-5 セメント改良体の内的安定結果

\begin{tabular}{|c|c|c|c|c|}
\hline & (構造物倸数 $\left.\gamma_{\mathrm{i}}=1.0\right)$ & 単位 & L1地震動 & L2地震動 \\
\hline \multirow{4}{*}{$\begin{array}{l}\text { 艺 } \\
\text { 断 }\end{array}$} & 設計世ん断力S & $\mathbf{k N}$ & 12.6 & 54.4 \\
\hline & 許容せん断強度 $\mathrm{S}_{\mathrm{a}}$ & $\mathbf{k N}$ & 3555 & 770.2 \\
\hline & ${ }^{*} \gamma_{\mathrm{i}} \cdot \mathrm{S} / \mathrm{S}$ & & $0.04<1.0$ & $0.07<1.0$ \\
\hline & 照査位置 & & 節点 3 & 節点 3 \\
\hline \multirow{4}{*}{ 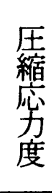 } & 設計圧縮応力度 $q_{1}$ & $\mathrm{kN} / \mathrm{m}^{2}$ & 1609 & 3023 \\
\hline & 許容圧縮応力度 $q_{a}$ & $\mathrm{kN} / \mathrm{m}^{2}$ & 13083 & 2635.1 \\
\hline & ${ }^{*} \gamma_{\mathrm{i}} \cdot \mathrm{q}_{1} / \mathrm{q}_{\mathrm{q}}$ & & $0.12<1.0$ & $0.11<1.0$ \\
\hline & 照査位置 & & 節点 9 & 節点 9 \\
\hline \multirow{4}{*}{ 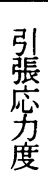 } & 設計引張応力度 $q_{2}$ & $\mathrm{kN} / \mathrm{m}^{2}$ & 0 & -39.0 \\
\hline & 許容引張応力度 $\sigma_{t}$ & $\mathrm{kN} / \mathrm{m}^{2}$ & 200 & 200 \\
\hline & ${ }^{*} \gamma_{\mathrm{i}} \cdot \mathrm{q}_{\mathrm{k}} / \sigma_{\mathrm{t}}$ & & - & $0.20<1.0$ \\
\hline & 照査位置 & & & 節点 6 \\
\hline
\end{tabular}

图-8＼cjkstart橋台く体の節点ばねモデル（単位：mm） 


\section{5. 従来形式橋台との比較検討}

\section{（1）設計方法の比較}

従来形式の逆T型橋台は, く体と 仮想背面盛土を一体として桁水平力 と背面盛土土圧に抵抗する構造であ る.これに対しセメント改良補強土 橋台はく体に地震時土圧を作用させ ず, 背面のジオテキスタイルで補強 されたセメント改良体が地震時水平 力に抵抗する構造である.

く体の安定検言は, 長期使用, 使 用限界状態では桁反力と死荷重に対 して照查し，L2地震時においては 両橋台とも設計転倒モーメントが支 持力から決まる最大抵抗モーメント を超えるため，塑性率照査を行った。

\section{（2）検封結果}

L2地震時の安定検討は, 両橋台形式とも塑 性率の制限值3.0以下であった。 なお，セメン 卜改良体はく体フーチング幅を加えた $(+1.5 \mathrm{~m})$ 基碐幅の場合に塑性率=1.6となり, 逆T型橋台と同程度の安全率であった.

部材の検討は，逆丁型橋台のく体は片持ち梁 として解くのに対して補强土橋台のく体は補强 材をバネ支点として解いている.このため逆T 型橋台く体の主鉄筋は，1m当りD29-8本（損傷 レベル2）必要だが，補強土橋台の主鉄筋は D25-5本(最小鉄筋量)で済み，経済的となった。

補強材 $(30 \mathrm{kN} / \mathrm{m}+60 \mathrm{kN} / \mathrm{m})$ の引張力, セメ ント改良体内部に生じるせん断力, 圧縮応力度 の照查については, 全ての設計力が許容值に対 して安全側となった.

なお，静的非線形解析による検討に加え，検 証の意味で施工過程（盛り立て $\rightarrow$ 壁面工打設 $\rightarrow$

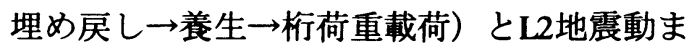
でを考虑した有限差分法での検討も行い，各部 の応力・変形挙動を把握し，その安全性を確認 している.

\section{（3）経済性とまとめ}

経済性の比較は表一に示すとおり, 補強土橋 台が逆型橋台に比べて鉄筋コンクリートは半 分以下となり, 補强材等を考虑しても全体比率 で17\%安価となった。

構造性, 施工性, 経済性について比較した結 果, セメント改良補強土橋台の長所は以下の 4 点が挙げられる.

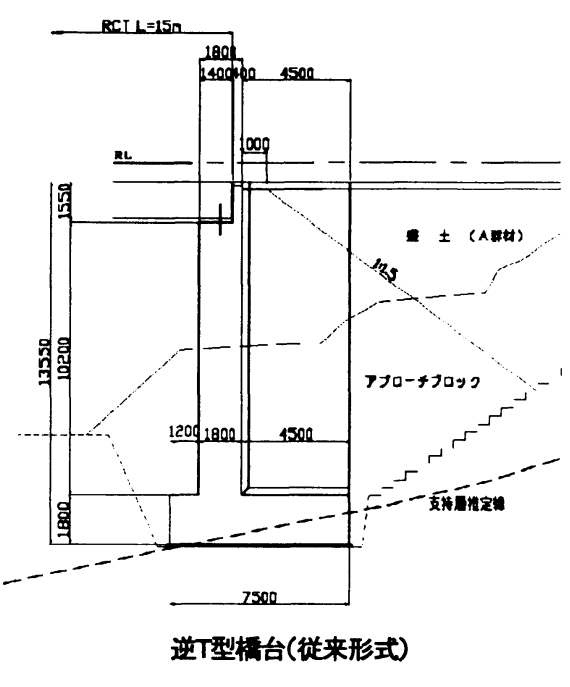

図-9 橋台形式比較図 (単位: mm)

表6 橋台形式此較表

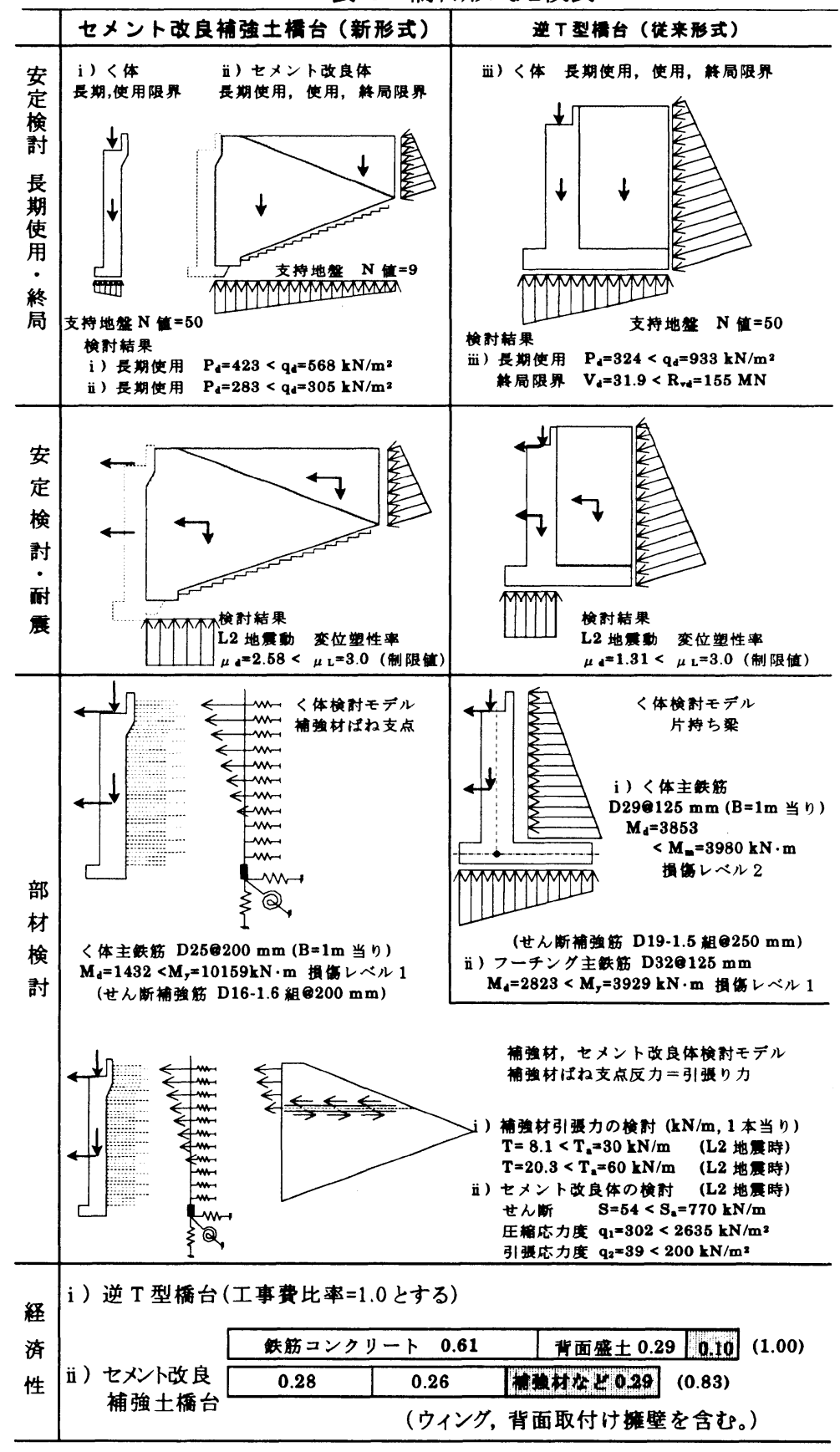


(1)改良体と補強材で連結することで，橋台の安定性 が飛躍的に向上し，摇込み沈下も軽减できる.

(2)セメント改良粒調砕石や補強材を用いて土压を軽 減するため, 従来橋台に比べく体やフーチングが スリムになる. 杭基礎の場合は杭本数が少なくフ 一チングも小規模となるため経済的である.

(3)橋台は補強土壁などの延長上で補強メカニズムや 施工を考えることができるため，新しい構造であ るにも関わらず，現場実務者に受け入れやすい.

(4)背面盛土の施工時に生じる盛土や地盤の沈下に影 響されることなく，く体部の施工が可能となる.

\title{
6. 実物大橋台の現地試験計画
}

図-10 に九州新幹線で予定されている実物大橋台によ る試験の側面図を示す。試験内容は, 各種計測計器を配 置しながら本橋台を構築した後, 施工性の調査, L2 地 震動を想定した水平載荷試験, 補強材の引抜き試験, 長 期動態計測等を実施 9 する予定である. 水平載荷試験は, 対面する橋脚を反力として，PC 鋼棒とジャッキにて橋 台に引張り水平荷重（L2 地震時水平桁荷重十<体慣性 力）を作用させる.ただし，橋台には桁の設計荷重相当 の鈆直荷重を作用させながら行う。

水平載荷試験での主な計測項目は, 橋台・橋脚の変 位，橋台く体の鉄筋ひずみ，フーチング底面反力，補強 材のひずみ，く体と改良体の相対変位，改良体の沈下， 改良体の底面反力などである.

\section{7. おわりに}

本橋台は模型振動実験，実施設計において十分な耐震 性を確保できること，従来の逆T型橋台に比べて耐震性 が向上（段差対策が付与）され，しかも合理的な断面と なることが確認された. 今後は実物大橋台の現地試験結 果を用いて検証解析を行い，設計・施工法の深度化を進 め，実構造物としての適用を図る予定である.

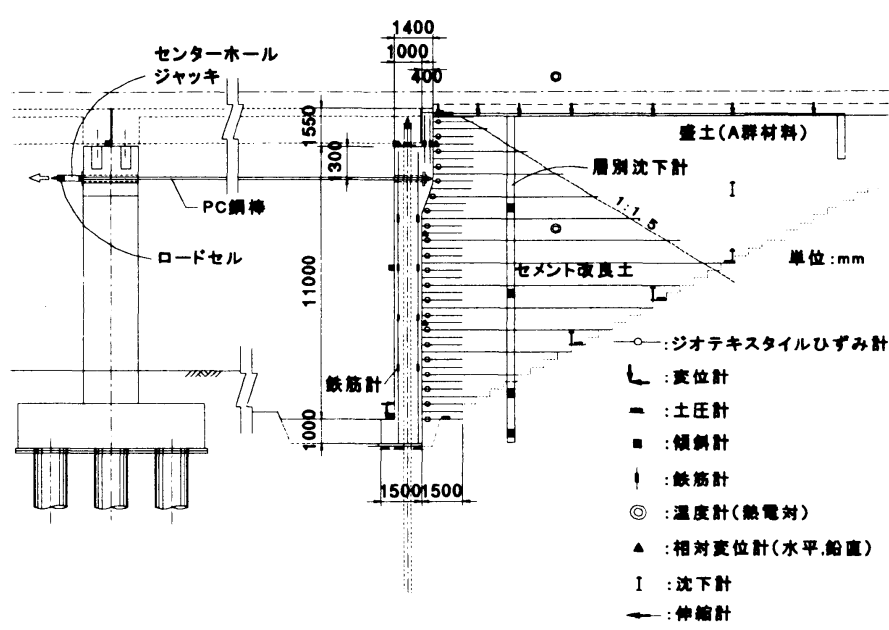

図-10＼cjkstart載荷試験装置と計測器の配置（単位.mm）

\section{参考文献}

1) 内村太郎·龍岡文夫 : PL·PS工法の新しい展開，土木技 術, 57巻2号, 2001.

2) 木村英樹·青木一二三・米澤豊司・舘山勝·古関潤一・龍岡 文夫：耐震強化した直接基䃈橋台の模型振動実験結果, 第35回地盤工学発表会, 2000.

3) 鈴木恒男·米澤豊司・山勝・小島謙一・龍岡文夫 ·木村英 樹：各種補強土橋台に関する模型振動実験結果, 第35 回地盤工学発表会, 2000.

4) 青木一二三・米澤豊司·舘山勝-小島謙一・大河内保彦·堀 井克己：耐震性橋台模型振動台実験の弹塑性FEMによ る動的解析, 第36回地盤工学研究発表会, 2001.

5) 渡辺健治·涻山勝·青木一二三・米澤豊司・古関潤一・龍岡文 夫：セメント改良補強土橋台に関する模型振動実験，第36回 地盤工学研究発表会, 2001.

6) 山田幸弘·涻山勝·青木一二三・米澤豊司·北野陽堂·矢崎澄 雄 : セメント改良補強土橋台の設計法の検討, 第 56 回土木 学会年次学術講演会, 2001.

7) 鉄道総合技術研究所 : 鉄道構造物等設計標準 ・ 同解説 基硞 構造物・抗士压構造物，丸善，2000。

8) 鉄道総合技術研究所 : 鉄道構造物等設計標準・同解説 而震 設計，丸善，1999.

9) 青木一二三·米澤豊司·北野陽堂·田村幸彦·舘山勝·龍岡文 夫 : セメント改良補強土橋台の現地試験計画，第57回土木 学会年次学術講演会, 2002

\section{Seismic Design of Reinforced Abutment with Cement Treated Backfill}

\author{
J.Kouhara, H.Aoki, T.Yonezawa and O.Watanabe, M.Tateyama, F.Tatuoka
}

Because of the experience of 1995 Hyougoken-Nanbu earthquake, the improvement of seismic resistance of the entire abutment system, including the abutment itself and the backfill, has become an important topic recently. In this study, based on the concept of reinforced abutment with cement-treated backfill, the comparison between this kind of newly developed abutment system, applied to the current railway construction, and the reversed T-shape abutment has been conducted. According to the results, it can be found that reinforced abutment with cement-treated backfill performs superiorly to the usual abutment so far both in the capacity of seismic resistance and the economical point of view. 